\title{
ICT MANAGEMENT FOR GREEN COMPETITIVENESS IN THE BANKING SECTOR
}

\author{
Nour NASSAR (D), Manuela TVARONAVIČIENE்(1)* \\ Department of Business Technology and Entrepreneurship, Faculty of Business Management, \\ Vilnius Gediminas Technical University, Sauletekio al. 11, LT-10223 Vilnius, Lithuania
}

Received 26 February 2021; accepted 01 April 2021

\begin{abstract}
Purpose - since ICT is an engine of green competitiveness in the banking sector, we aim to know in what banking field we must focus more on the use of ICT to ensure efficient green competitiveness.

Research methodology - PRISMA-SCR (Preferred Reporting Items for Systematic reviews and Meta-Analyses for Scoping Reviews) were used to develop a greater understanding of relevant terminology, core concepts, and key items to report for scoping reviews.

Findings - ICT management has a positive influence on banking competitiveness, especially in the digital banking field. Research limitations - researching the banking sector limits the possibility of generalizing the results to other types of business sectors as well as other geographical areas.

Practical implications - conducted research results have practical value for banks as this will guide the managers to emphasize the use of ICT in the right field which is digital banking to achieve better results.

Originality/Value - this research investigated one of the rare studies in the banking sector, where we study the drivers of green competitiveness, which is the modern version of the traditional bank.
\end{abstract}

Keywords: green competitive advantage, green competitiveness, sustainability, sustainable management, ICT, industry 4.0.

JEL Classification: M15, O32.

Conference topic: Business Processes: Development, Digitalization, Social Responsibility.

\section{Introduction}

Traditional banking has become a thing of the past as significant demographic, cultural, technical, economic, regulatory, and legitimacy changes affect the feasible existence of current business models (Soebandrija, 2019).

Nowadays, more and more customers of many traditional banks are seeking green financial products and investment opportunities, and many of them would also like to become familiar with the environmental concerns of people as doing good. Industry 4.0 is the next wave of the industrial revolution, where production is improved, flexible, customized, and has better quality. Changes allow businesses to face challenges and to seek competitiveness.

ICT is a part of Industry 4.0 and our main focus in this paper. Thus, one of the best definitions of ICT is provided by authors, who indicated that all the elements, which are needed for the "processing, storing and transfer of information" to both internal users and external partners (Cragg \& McNamara, 2018). ICT is considered as one of the success factors in banking competence since it helps banks to improve their business productivity.

ICT has been proved to be essential for competitiveness since it enables quick responses to a dynamic market. The credibility of the environment is essential today for banks' economic achievement.

The evolution of digital technology has influenced the global banking industry. Therefore, it will create measures to gain hung competitive advantage and to create financial stability and integrity. Traditional banks will change their operations to meet industry 4.0 (Shkodina et al., 2019). ICT value and financial factors vary from industry to industry at different levels of technological development. This article aims to highlight the latest literature review on ICT, banking, and competitiveness.

\footnotetext{
*E-mail: manuela.tvaronaviciene@vilniustech.lt
} 
Since ICT is an engine of green competitiveness in the banking sector, we aim to know in what banking field we must focus more on the use of ICT to ensure efficient green competitiveness. Should we emphasize more on the use of ICT in the Human Resources field, or the supply chain field, or the IT field? After summarizing the previous research in this era, a new interpretation is done based on a systematic review.

The results contribute to a general conclusion showing the importance of ICT use to achieve competitiveness in the banking sector, especially in the digitalization era. The findings of analysis have real relevance for banks as this study analyzes the principle of ICT-based management that affects Green competition, which affects organizational success. Concerning the issue of ICT management for green competition in the banking sector, it is important to know the most important area of study based on the most recent literature review. The outcome would then allow managers to look further into the right area, which is digital banking.

\section{Previous research}

The complex interaction of actors in value networks (VNs) relies heavily on both knowledge transfer and information and communication technology (ICT) to respond to customer needs. On the one hand, data is seen in the sense of a $\mathrm{VN}$ as a source of competitiveness. They found that the issues of knowledge transfer and ICT are no longer limited to single companies, but have become issues across a value network (Bagheri et al., 2016). In the meantime, business managers and IT administrators must combine their skills to better understand and address all issues at the same time to facilitate the transfer of knowledge.

Grant and Yeo (2018) examined the global performance across industries, at various levels of technological development, ICT, strategic investments, and financial factors. Studies have shown that well-implemented ICT programs can positively impact a firm's internal operations, as well as supply chain processes, and, in the case of SMEs, resulting in higher profitability than those firms that neglected ICT. Companies should encourage their employees to acquire the training and skills needed to become experts in the use of ICT (Cragg \& McNamara, 2018). Results show that the ability to analyze big data has a significant impact on the innovative development of green products and sustainable supply chains. For the sustainable supply chain, innovation and learning success plays an essential moderating role (Bag et al., 2020).

A study examined how complementarily between information sharing offices and ICT affects the market power within the African banking industry(Asongu \& Biekpe, 2018). Power reduction is significant, as previous studies have shown that this reduces investment volumes and savings, raises financial intermediation costs, and eventually lowers economic growth. Information sharing with ICTs will significantly reduce internal rentals and confidentiality barriers: improving accountability, through tracking and adjusting cost-benefit calculations. The basis of this argument is that the intelligence monopoly provides abuse of power. Such possibilities for power abuse are thus restricted theoretically by liberalization and decentralization of information across ICT networks.

In short, the underlying postulations are mainly consistent with the emerging literature on the relations between governance, ICT, and the elite abuse of power with privileges, on the one hand, and the deteriorating array of studies on the role of ICTs in collective action to tackle power abuse, on the other (Rahman \& Barua, 2016).

Forty-three percent of customers surveyed favored banks with green initiatives (Green Wiki, 2013), according to a recent study from Javelin Strategy and Analysis. A violation of the license requirements issued by comprehensive emission prevention measures in the United Kingdom will lead to prohibitions and financial penalties against polluting businesses and the introduction of compliance notices (Asongu \& Biekpe, 2018).

Some classic studies have shown that environmental performance is closely linked with financial performance and that banks suffer from financial risks because, in business practice, they do not have environmental considerations. The analysis shows that value creation variables contribute to the environmental aspect of sustainability in most situations (Stock et al., 2018). A study (Junge, 2019) has concluded that the economic aspect of sustainability has the most significant impact.

The key objectives of digital transformation are: achieving greater competition, having client-centered practices, and seeking cost reductions. Critical areas are defined and addressed with projected negative impacts in connection with the computing, materials used, and primary energy use. Possible effects have been built on social sustainability. The advantages of this sustainable aspect can be anticipated to improve workplace engagement and inclusion, job development, better education for worker creation, and the quality of working life. Negative consequences may arise from replacing or simplifying employment via software systems, as well as the ability to control and complete transparency of ICT work, which could contribute to worker abuse and productivity extorsion.

Previous authors (Shkodina et al., 2019) conducted that the leading segments in banking where significant changes occur are in retail and corporate banking, banking transactions as payments, investment banking, and infrastructure projects. Based on e-banking, the banks strengthen and develop new e-banking services and platforms with considerable advantages. An important and challenging problem for e-banking is the integration of heterogeneous, autonomous, and distributed data sources (Themistocleous et al., 2015). ICT is measured with mobile phone and 
internet penetration and showed that there are positive on financial complexity and financial activity at the level of the banking and financial system with secure ICT-driven information sharing thresholds (Asongu et al., 2019). ICT has been developed to promote sustainability in a variety of ways, such as living standards, better lives for all, social welfare issues, economic growth, and sustainable growth.

To reduce asymmetry between lenders and borrowers, ICT can improve the role of information-share agencies. ICT can provide banks with timely and comprehensive information on credit history for borrower information-sharing offices. Studies have found a value of human touch even in the ICT era. They have studied the relevance of digital banking or ICT-based distribution networks, products, and services of the traditional banks and of the delivery channels, which facilitated the customer's direct communication with their bank staff. It is noted that even during this age, 'human touch' is essential (as in traditional banking) (Katta et al., 2019).

Another study showed that the operational efficiency and competitiveness of commercial banks could be increased by data mining technology if effectively implemented and has demonstrated significant and strategic benefits for data mining technologies. To improve their competitiveness and deal with changes in the industry and meet international standards, most of the banks have recruited more Specialist Officers in various fields such as treasury management, credit risk management, ICT-related services, and Human resource (HR) management. As the ICT industry overgrows and the competition is increased, HR performance is more important than quantity. Banks reduce the volume and enhance HR quality. Banks need high-quality HR to work better and more efficiently for this very competitive situation. Besides, to improve ICT infrastructures and improve profit and productivity, it is also vital to ensure that the "personal factor" (soft staff skills) is provided.

Banks need to boost their operational efficiency to increase profitability. In this age of digital transformation and increasing customers, ICT adoption is the only way of improving operational efficiency. ICT-based products and services and new distribution networks shall be provided to customers. In this regard, otherwise, than traditional customer relationship management (CRM), new solutions like e-CRM would be widespread. Together with ICT adoption and more services, which attract the most distinguished modern customers, the focus should be on the "human factor" or the "human touch" of service.

As previous studies have shown, even in this era of ICT and robotics, the human factor is essential for banking. In the case of the related abilities like integrity, eye contact, co-operation, ethical behavior, auto control, punctuation, etc., besides the human element as above, a thrust is required. Besides, motivational training, social skills, etc. are vital to the success and productivity of the employees in this ICT era.

Another study explains the importance of soft knowledge in critical decision-making on loans. The bank's application of ICT management gains a competitive advantage. Therefore, Regional banks need to strengthen their competitive position further because replacing other business areas with SME surpluses is becoming increasingly difficult (Flögel \& Beckamp, 2019). Enhanced cooperation between regional banking groups with FinTech companies can improve the competitiveness of the bank-ICT for loans. Maixé-Alté mentioned in a study that Retail banking has been significantly affected in the context of developments in computer technology (Maixé-Altés, 2015).

Thus, the development of national data centers in Sweden, Denmark, Norway, and Finland was outstanding. EDP (The Electronic Data Processing) cooperation, took a significant step forward in the 1960s. Economically speaking, savings banks were needed to improve the banking sector's productive performance and to increase competition from trade banking. New computers increased the prospect of revising banking administration to simplify back office and head office procedures.

In contrast with the Nordic model, the US savings banks are characterized by large companies with few and large branches not far away from the headquarters with the various branches distributed across a wide geographical area. It was viewed in Sweden and Denmark as a barrier against isolated national solutions to the need to build on the online systems and high development cost, based on the equipment available, especially the counters (Maixé-Altés, 2015). The position of third-generation computers was very significant because they opened up a real-time online development area that is required for institutions like several European savings banks that covered extensive branch networks. For example, in the late 1960s, Swedish savings banks had intense competition in the branch networks of commercial banks, which was another reason why concentration in the sector was continually changing.

With new computer networks and online connections, Retail Banking revolutionized its advantages. The majority of banks have adopted and used e-banking services as significant benefits are associated with it. The average European adoption rate is now estimated to be $60 \%$ in 2020. In 2015 one-third of Europeans were using E-banking. This shows that e-banking is a large and rapidly growing field (Themistocleous et al., 2015).

International organizations underline the value of e-banks and highlight their potential for better access to finance. The key reason for the success of e-banking is that it provides banks, consumers, businesses, government organizations, as well as other non-profit organizations with a range of benefits as accessibility, reliability, and cost savings (Themistocleous et al., 2015).

Other researchers have studied the factors of the online finance service as an alternative to traditional financial intermediaries, including banks. The convergence of' traditional' and' alternative' financing will minimize their disadvantages and weaknesses and bring additional benefits for all financial participants (Bilan et al., 2019). 
Banks have a significant regulatory role in ensuring the integrity of the financial system as a whole. In many countries around the world, the regulation of alternative online financing is fragmented and uncertain. The annual growth of the use of alternative financing will endanger financial stability in macroeconomic ways.

In the Financial Services industry, digitalization and computerization lead to significant changes. Only the fourth industrial revolution made it possible by processing information and operating online platforms in all areas of society and business.

The banking industry has established Internet banking rapidly as an effective and viable means of generating value for the consumer. The fast growth of computer technology as commercial or Internet banking is an advocate for more consumers in relevant banks. It is one of the conventional banks' popular services to provide quick and reliable services for online users.

One of the efficient ways to enhance service quality and meet customer requirements is through technological innovations. The customers of traditional banks have become more familiar with Internet banking through advanced technology and innovation in the financial and banking sectors.

Retail banks provide Internet banking in many developed countries, and consumers can transact without having to leave their homes or workplaces. Internet banking can also assist customers in the efficient management of their finances. Satisfied customers are essential in helping banks to retain competitive advantages (Ling et al., 2016).

Content and website quality, security and privacy, convenience, and speed are the five key factors that can influence customer satisfaction for Internet banking. The problem facing Internet banking companies, however, is that many of the banks' clients are unable to use their Internet banking services. This was because Internet banking companies have not yet reached their clients.

The results show that web design and content, usability, and speed are related closely to customer satisfaction in the context of internet banking. Such research findings have shown that web design and content, usability, and speed are the three main factors impacting customer satisfaction with Internet Banking (Ling et al., 2016).

This research can help find a link between enhancing the performance of the bank in a trendy sustainable way (industry 4.0) by enhancing internet banking.

Internet banking can help providers of Internet banking easily reach customer satisfaction. Internet banking providers know their views and find the solution from the customers' point of view. A study has analyzed the patterns and risks of global banking digital transformation and concluded that there is a gap in banking digitalization in various regions (Shkodina et al., 2019).

The use of digital technology increases competition and the competitiveness of the economy. It creates new systemic risks to financial stability and credibility and raises the systemic risks associated with cybersecurity, fraud, and ethical issues, one of the biggest dangers of digital banking business transformation.

\section{Methodology}

To explore the world of competitiveness and sustainability, we adopted Preferred Reporting Items for Systematic reviews and Meta-Analyses for Scoping Reviews (PRISMA-SCR) to develop a greater understanding of relevant terminology, core concepts, and key items to report for scoping reviews.

We started searching for the link between "Banking" and "ICT" using it as keywords. Note that the Databases were exclusively WOS, KJD, RSCI, and SCIELO for the Timespan equal to the Last 5 years (2015-2020) and we have limited our Search language to English. Since we got an important number of researches done in this field, we decided to go deeper to find the link between "Banking", "ICT" and "competitiveness".

We stated (see Table 1) the spectrum of ICT management and green competitiveness whereas per the recent authors' studies we could detect an overall relationship between ICT and green competitiveness that has a positive impact on the organization's performance.

Then, we detected the frequency of the most highlighted studied topics. For example, we noticed that Digital banking has been stated in 13 recent articles, Intelligent manufacturing systems (IMS) has been stated in 4 recent articles and Supply chain management has been stated in 3 recent articles.

\section{Results and discussion}

The results of this research highlight the positive influence of the use of ICT Management in the following fields: Digital banking, Intelligent manufacturing systems (IMS), Supply chain management, Handling information resources, Knowledge management system (KMS), Human resources management and, Social sustainability.

This article has highlighted the most important studied fields about ICT, banking, and competitiveness. As a result, our findings show that $49 \%$ of the covered topics were related to digital banking and the other fields come after (Figure 1). This indicates the importance of the use of ICT to achieve competitiveness, especially in the digitalization era. Therefore, sustainable ICT management has a positive influence on banking competitiveness, especially in the digital banking field. The results also show that the most highlighted ICT index is related to the ICT use index where the other index comes second as the ICT readiness index and to the ICT skills index. 
Table 1. The spectrum of ICT management and green competitiveness (source: formed by the authors)

\begin{tabular}{|c|c|c|c|c|c|c|c|c|c|c|}
\hline$\underset{i}{\stackrel{2}{E}}$ & 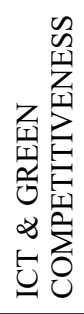 & 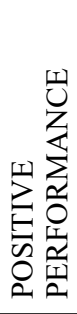 & \multirow{13}{*}{$\sqrt{\hat{O}}$} & 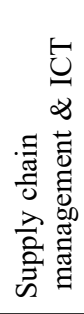 & 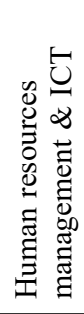 & 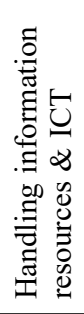 & 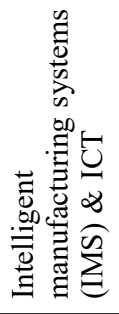 & 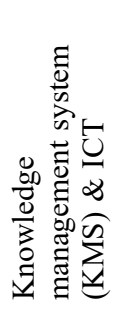 & 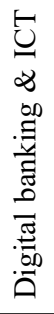 & 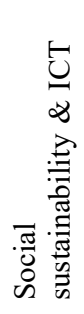 \\
\hline (Cragg \& McNamara, 2018) & $\mathrm{X}$ & $\mathrm{X}$ & & $\mathrm{X}$ & $\mathrm{X}$ & & & & & \\
\hline (Zhong et al., 2017) & $X$ & $\mathrm{X}$ & & & & $\mathrm{X}$ & $\mathrm{X}$ & & & \\
\hline (Bagheri et al., 2016) & $X$ & $\mathrm{X}$ & & & & & & $\mathrm{X}$ & & \\
\hline (Junge, 2019) & $\mathrm{X}$ & $\mathrm{X}$ & & $\mathrm{X}$ & & & & & & \\
\hline (Katta et al., 2019) & $\mathrm{X}$ & $\mathrm{X}$ & & & & & & & $X$ & \\
\hline (Stock et al., 2018) & $\mathrm{X}$ & $\mathrm{X}$ & & & & & & & & $\mathrm{X}$ \\
\hline (Shkodina et al., 2019) & $\mathrm{X}$ & $\mathrm{X}$ & & & & & & & $\mathrm{X}$ & \\
\hline (Maixé-Altés, 2015) & $\mathrm{X}$ & $\mathrm{X}$ & & & & & & & $X$ & \\
\hline (Themistocleous et al., 2015) & $X$ & $\mathrm{X}$ & & & & & & & $\mathrm{X}$ & \\
\hline (Asongu \& Biekpe, 2018) & $X$ & $\mathrm{X}$ & & & & & & & $\mathrm{X}$ & \\
\hline (Rahman \& Barua, 2016) & $\mathrm{X}$ & $\mathrm{X}$ & & & & & & & $\mathrm{X}$ & \\
\hline (Asongu et al., 2019) & $\mathrm{X}$ & $\mathrm{X}$ & & & & & & & $\mathrm{X}$ & \\
\hline (Flögel \& Beckamp, 2019) & $X$ & $\mathrm{X}$ & & & & $\mathrm{X}$ & & $X$ & & \\
\hline (Bilan et al., 2019) & $\mathrm{X}$ & $\mathrm{X}$ & & & & & & & $\mathrm{X}$ & \\
\hline (Soebandrija, 2019) & $X$ & $\mathrm{X}$ & & & & & & & $X$ & \\
\hline (Bag et al., 2020) & $\mathrm{X}$ & $\mathrm{X}$ & & $\mathrm{X}$ & $X$ & & & & & \\
\hline (Martins et al., 2019) & $\mathrm{X}$ & $\mathrm{X}$ & & & & & $\mathrm{X}$ & & $\mathrm{X}$ & \\
\hline (Ling et al., 2016) & $\mathrm{X}$ & $\mathrm{X}$ & & & & & & & $\mathrm{X}$ & \\
\hline (Grant \& Yeo, 2018) & $\mathrm{X}$ & $\mathrm{X}$ & & & & & $\mathrm{X}$ & & $\mathrm{X}$ & \\
\hline (Caruso, 2018) & & & & & & & $\mathrm{X}$ & & $\mathrm{X}$ & \\
\hline
\end{tabular}

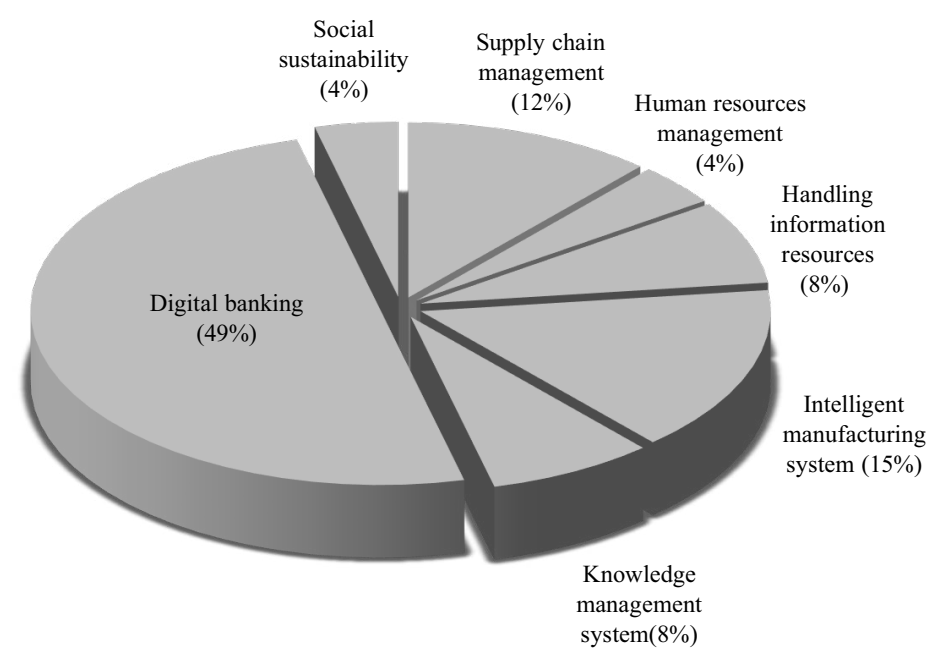

Figure 1. Latest ICT topics in the banking sector covered in the literature review (source: formed by the authors)

The results of this research highlight the positive influence of the use of ICT Management in the following fields: Digital banking, Intelligent manufacturing systems (IMS), Supply chain management, Handling information resources, Knowledge management system (KMS), Human resources management and, Social sustainability.

This article has highlighted the most important studied fields about ICT, banking, and competitiveness. As a result, our findings show that $49 \%$ of the covered topics were related to digital banking and the other fields come after. This indicates the importance of the use of ICT to achieve competitiveness, especially in the digitalization era. Therefore, 
sustainable ICT management has a positive influence on banking competitiveness, especially in the digital banking field.

The results also show that the most highlighted ICT index is related to the ICT use index where the other index comes second as the ICT readiness index and to the ICT skills index.

\section{Conclusions}

Conducted research results have practical value for banks as this study analyses the concept of ICT-based management that influences Green competitiveness, which has an impact on organizational performance.

ICT is considered as one of the success factors in banking competence since it helps the banks to improve their business productivity. ICT has been proved to be essential for competitiveness since it enables quick responses to a dynamic market. The use of ICT facilitates the handling of information resources and results in cost reduction and the increase of client compliance.

This article shows that achieving green competitiveness in the banking sector is a critical factor. Therefore, Integrating ICT solutions might not show an immediate improved competitive position for the banks. However, it usually leads to the development of competencies that could provide results in the future. Furthermore, once ICT competencies have been developed, implemented, and exploited, they represent a competitive capability that cannot be easily duplicated by a rival firm (Cragg \& McNamara, 2018).

ICT's creations represent all of the future's images and expectations. The hopes of continuous transition, economic growth, capacity-building, and perhaps democratization lie with modern ICTs and the fears of totalitarian control, displacement, job loss, and unemployment (Caruso, 2018).

The terms "Industry 4.0" and "Fourth Industrial Revolution" (FIR) now apply to a broad-based transformation of goods and services output that emerges from the implementation of new technological innovation waves as autonomous robots integrated, machine learning, and artificial intelligence (Caruso, 2018).

This research aims to help the researchers to investigate one of the rare studies, where we study the drivers of green competitiveness in the banking sector, which is the modern version of the traditional banks.

Concerning the topic of ICT Management for green competitiveness in the banking sector, it's important to know the most important studied field based on the latest literature review. Therefore, the result will help the managers to investigate deeper in the right field which is digital banking.

In parallel, due to the importance of the ICT index as per our findings, future researchers can use it for further studies and scopes.

Researching the banks limits the possibility of generalizing the results to other types of business sectors.

Moreover, previous research studies that apply to this paper could be limited, depending on the nature of the research topic in addition to the Databases that were exclusively WOS, KJD, RSCI, SCIELO for the Timespan equal to the last 5 years (2015-2020) in the English language.

\section{Disclosure statement}

Authors declare that they do not have any competing financial, professional, or personal interests from other parties.

\section{References}

Asongu, S. A., Anyanwu, J. C., \& Tchamyou, V. S. (2019). Technology-driven information sharing and conditional financial development in Africa. Information Technology for Development, 25(4), 630-659. https://doi.org/10.1080/02681102.2017.1311833

Asongu, S. A., \& Biekpe, N. (2018). ICT, information asymmetry and market power in African banking industry. Research in International Business and Finance, 44, 518-531. https://doi.org/10.1016/j.ribaf.2017.07.121

Bag, S., Wood, L. C., Xu, L., Dhamija, P., \& Kayikci, Y. (2020). Big data analytics as an operational excellence approach to enhance sustainable supply chain performance. Resources, Conservation and Recycling, 153, 104559. https://doi.org/10.1016/j.resconrec.2019.104559

Bagheri, S., Kusters, R. J., \& Trienekens, J. J. M. (2016). An integrated framework of knowledge transfer and ICT issues in co-creation value networks. Procedia Computer Science, 100, 677-685. https://doi.org/10.1016/j.procs.2016.09.211

Bilan, Y., Rubanov, P., Vasylieva, T., \& Lyeonov, S. (2019). The influence of Industry 4.0 on financial services: Determinants of alternative finance development. Polish Journal of Management Studies, 19(1), 70-93. https://doi.org/10.17512/pjms.2019.19.1.06

Caruso, L. (2018). Digital innovation and the fourth industrial revolution: Epochal social changes? AI \& Society, 33, $379-392$. https://doi.org/10.1007/s00146-017-0736-1

Cragg, T., \& McNamara, T. (2018). An ICT-based framework to improve global supply chain integration for final assembly SMES. Journal of Enterprise Information Management, 31(5), 634-657. https://doi.org/10.1108/JEIM-04-2014-0038

Flögel, F., \& Beckamp, M. (2019). Will FinTech make regional banks superfluous for small firm finance? Observations from soft information-based lending in Germany. Economic Notes. 49(2), e12159. https://doi.org/10.1111/ecno.12159 
Grant, D., \& Yeo, B. (2018). A global perspective on tech investment, financing, and ICT on manufacturing and service industry performance. International Journal of Information Management, 43, 130-145. https://doi.org/10.1016/j.ijinfomgt.2018.06.007

Green Wiki. (2013). Green Banking. Fandom. Retrieved May 28, 2020 from https://green.wikia.org/wiki/Green_Banking\#

Junge, A. L. (2019). Digital transformation technologies as an enabler for sustainable logistics and supply chain processes - an exploratory framework. Brazilian Journal of Operations \& Production Management, 16(3), 462-472. https://doi.org/10.14488/BJOPM.2019.v16.n3.a9

Katta, A. K., Subbarao, P., \& Ramana, S. V. (2019). HRD - Banks in the ICT Era a Focus on Private sector Banks. Journal of Mechanics of Continua and Mathematical Sciences, 14(5), 943-957. https://www.journalimcms.org/wp-content/uploads/76HRD-Banks.pdf

Ling, G. M., Fern, Y. S., Boon, L. K., \& Huat, T. S. (2016). Understanding customer satisfaction of internet banking: A case study in Malacca. Procedia Economics and Finance, 37, 80-85. https://doi.org/10.1016/S2212-5671(16)30096-X

Maixé-Altés, J. C. (2015). ICT the Nordic way and European retail banking. In IFIP Advances in Information and Communication Technology: Vol. 447. History of Nordic Computing 4 (pp. 249-262). Springer. https://doi.org/10.1007/978-3-319-17145-6_27

Martins, G. D., Gonçalves, R. F., \& Petroni, B. C. (2019). Blockchain in manufacturing revolution based on machine to machine transaction: A systematic review. Brazilian Journal of Operations \& Production Management, 16(2), $294-302$. https://doi.org/10.14488/BJOPM.2019.v16.n2.a10

Rahman, S. M. M., \& Barua, S. (2016). The design and adoption of Green Bnaking framework for environment protection: Lesson from Bangladesh. Australian Journal of Sustainable Business and Society, 2(1), 1-19.https://ssrn.com/abstract=2854072

Shkodina, I., Derid, I., \& Zelenko, O. (2019). Digital transformation of global banking: Challenges and prospects. Financial and Credit Activity: Problems of Theory and Practice, 3(30), 45-51.

Soebandrija, K. E. N. (2019). Dynamic capability and disruptive innovation within perspectives of industry 4.0, research result and innovation on people's prosperity. In IOP Conference Series: Materials Science and Engineering: Vol. 508. Tarumanagara International Conference on the Applica-tions of Technology and Engineering, 22-23 November 2018. Jakarta, Indonesia. https://doi.org/10.1088/1757-899X/508/1/012101

Stock, T., Obenaus, M., Kunz, S., \& Kohl, H. (2018). Industry 4.0 as enabler for a sustainable development: A qualitative assessment of its ecological and social potential. Process Safety and Environmental Protection, 118, 254-267. https://doi.org/10.1016/j.psep.2018.06.026

Themistocleous, M., Basias, N., \& Morabito, V. (2015). A framework for service-oriented architecture adoption in e-banking: The case of banks from a transition and a developed economy. Information Technology for Development, 21(3), 460-479. https://doi.org/10.1080/02681102.2014.939605

Zhong, R. Y., Xu, X., Klotz, E., \& Newman, S. T. (2017). Intelligent manufacturing in the context of Industry 4.0: A review. Engineering, 3(5), 616-630. https://doi.org/10.1016/J.ENG.2017.05.015 